\title{
TRUST IN STRUCTURE OF RESILIENCE OF INDIVIDUAL
}

\section{ДОВЕРИЕ В СТРУКТУРЕ ЖИЗНЕСТОЙКОСТИ ЛИЧНОСТИ}

\section{Kravchenko Viktoria ${ }^{1}$}

DOI: https://doi.org/10.30525/978-9934-571-78-7_45

Abstract.The request for the viability of the personality in modern society is so great that it requires constant scientific research. This explains the choice of the topic of our study. One of the components of the viability of the individual is trust, which ensures the balance of the external and internal in the structure of the individual. Equilibrium of trust in oneself and trust in the world ensures the individual's output to a new level of disclosure of personal potential and creates new prospects for development. In the process of forming a dynamic equilibrium of trust in the world and confidence in oneself, the life-stability of the individual is formed as the ability to overcome difficulties. An empirical study confirms that trust is the determining factor in the formation of viability in adolescence. The resources of actualization of trust and vitality at the time of youth are the activity and cognitive activity of a single individual, life experience, is in the continuum «parent scenario - self-reflection», friendship and love relations, search for authenticity and the development of dialogicity.

\section{1. Введение}

Современное информационное общество прямо и косвенно, а следовательно, непрерывно влияет на жизнедеятельность индивида. Нестабильность социально-экономической и политической систем, перегруженность информационного пространства, увеличение количества катастроф выступают экстремальными факторами, стимулирующими развитие стресса. Это приводит к поиску индивидуальных путей эффективного существования в экстремальных жизненных условиях, что является вызовом современности. Социально-психологической предпосылкой качественного жизненного моделирования можно считать жизнестойкость.

\footnotetext{
${ }^{1}$ Candidate of Psychological Sciences, Associate Professor, Head of the Department of Social Sciences, Ivano-Frankivsk National Technical University of Oil and Gas, Ukraine
} 
Научной новизной данного исследования является определение места и роли доверия в структуре жизнестойкости личности. Цель исследования - теоретически обосновать и эмпирически выявить связь между доверием и жизнестойкостью личности. Согласно поставленной цели сформулированы задачи исследования: на основе теоретико-методологического анализа проблемы определить сущность жизнестойкости личности и доверия; обосновать структурную модель доверия к себе; на эмпирико-диагностическом уровне исследовать проявления доверия в структуре жизнестойкости личности; определить ресурсы актуализации доверия и жизнестойкости в юношеском возрасте. Методологической основой исследования является субъектный подход в психологии. Логика изложения исследовательского материала подается в соответствии цели, задач исследования и последовательности его реализации.

\section{2. Доверие как составляющая жизнестойкости личности}

Жизнестойкость (англ. hardiness) - это фундаментальная личностная характеристика, которая лежит в основе способности личности преодолевать неблагоприятные обстоятельства жизни [26, с. 288]. Эта личностная черта позволяет выдерживать стрессовую ситуацию, сохраняя внутреннюю сбалансированность, при этом не понижая успешность деятельности и удовлетворение своей жизнью.

Отечественные и иностранные авторы по-разному рассматривают содержание понятия «жизнестойкость». Жизнестойкость отождествляют с личностным адаптационным потенциалом, который определяет устойчивость человека к экстремальным факторам (А.Г. Маклаков). Понятие личностного потенциала как интегрированной характеристики уровня личностной зрелости и самодетерминации способствует преодолению личностью самой себя и обстоятельств своей жизни за счет воли, силы Эго, внутреннего сопротивления, локуса контроля, что в целом соответствует сущности жизнестойкости личности (Д.А. Леонтьев). Жизнестойкость связывают с психологическими факторами преодоления стресса (Ла Грека), с копинг-стратегиями (Лазарус, Фолкман), с гибкостью в плане устойчивости в отношении принуждения к изменениям (Раш, Шоэл, Барнард), со здоровьем (Уильямс, Вибе, Смит) и т.д.

Рассмотрим структуру понятия «жизнестойкость», введенного С. Мадди. Она включает: включенность, контроль и принятие риска 


\section{Kravchenko Viktoria}

$[11$, с. 90]. Включенность определена как уверенность в том, что приобщение ко всему происходящему дает личности максимальный шанс найти для себя что-то стоящее и интересное. Что бы ни произошло вокруг, у человека должна быть установка включенности как осознание того, что жизнь достойна того, чтобы ее прожить, невзирая ни на какие обстоятельства. Если у человека надлежащий уровень включенности, то в сложных обстоятельствах он не будет замыкаться в себе и избегать контактов с окружающими. Человек с развитым компонентом включенности получает удовольствие от собственной деятельности. И наоборот, если такого убеждения нет, это порождает чувство отчужденности, пребывания «вне» жизни. Контроль - это убежденность в том, что благодаря борьбе можно повлиять на результат происходящего, даже если это влияние не является абсолютным и успех вовсе не гарантирован. Человек с хорошо развитым компонентом контроля чувствует, что самостоятельно выбирает свою деятельность, свой путь. Такой человек убежден, что благодаря ресурсам, которые у него есть или которых у него пока нет, но их можно получить, он может справиться с проблемами, возникающими на его пути. Если у человека хорошо выражен компонент контроля, он пытается влиять на события, а не бездействовать. Принятие риска - это убежденность человека в том, что все, что с ней происходит, служит ее развитию, который происходит за счет знаний, полученных из опыта (неважно - положительного или отрицательного). Человек, рассматривающий жизнь как способ получения опыта, готов действовать в условиях, когда нет стопроцентной гарантии успеха, на свой страх и риск. Такой человек считает, что стремление к обыденному комфорту и безопасности очень обедняет жизнь личности. В основу принятия риска положена идея развития благодаря активному усвоению знаний из опыта и дальнейшему их использованию. Принятие риска дает человеку возможность учиться на собственной жизни, собственном опыте, а не надежду на легкую, беззаботную жизнь [26, с. 293].

Л.А. Александрова добавляет к этим составляющим еще такие: базовые ценности, кооперацию, креативность и доверие [1, с. 82]. Доверие в структуре жизнестойкости личности является предметом нашего исследования, поэтому проанализируем более подробно.

Доверие - это способность человека априори наделять явления и объекты окружающего мира, а также других людей, их будущие дей- 
ствия и свои действия свойствами безопасности (надежности) и ситуативной полезности (значимости) [22, с. 85]. Существует очень много видов доверия, социально-психологических функций и характеристик доверия, однако в нашем контексте мы будем рассматривать только относящиеся к разряду социальных отношений и взаимодействий в системе «человек - человек», а не «человек - общество» или «человек - вселенная». Выделяют следующие виды доверия: доверие к миру, доверие к другим и доверие к себе. При этом каждый из этих аспектов изучался в психологической науке обособленно. Доверие к другим изучалось в контексте социально-психологических проблем; доверие к себе выступало предметом психотерапевтических и психокоррекционных процедур; доверие к миру рассматривалщсь как базовая установка личности [22, с. 76].

С целью определения назначения доверия выделяют такие социально-психологические функции доверия:

- познавательная - доверие обеспечивает связь с миром; двойственность направленности психики индивида предполагает наличие доверия к миру (как условия взаимодействия с миром) и доверия к себе (как условия активности личности) [22, с. 234];

- интерактивная - доверие является фундаментальным условием взаимодействия с миром; характеризуется установлением межличностных отношений и организацией совместной деятельности [22, с. 233];

- адаптационная - доверие способствует целостности бытия личности; реализуется путем соотношения доверия к себе и доверия к миру, находящегося в состоянии динамического равновесия [22, с. 235];

- интегративная - доверие - механизм, интегрирующий внешние и внутренние условия индивида, делая их соотносительными друг к другу в субъективном мире каждого конкретного человека [22, с. 234];

- ориентировочная - доверие способствует слиянию прошлого, настоящего и будущего в единый целостный акт жизнедеятельности; определяется прошлым опытом человека и невозможно без веры в правильность и реальность прогнозируемых поступков, поставленных целей, выражающихся в нынешних взглядах и действиях человека [22, с. 235];

- регулятивная - доверие выступает мерой соотнесения поведения, целей, поставленных задач как к миру, так и к себе; чувство гармонии в отношениях с миром и с самим собой [22, с. 235]; 


\section{Kravchenko Viktoria}

- коммуникативная - соответствующее количество (мера) доверия превращает акт передачи, трансляции информации в полноценный акт общения, что является важным в учебном и воспитательном процесcax $[4$, c. 61$]$, а отсюда следует воспитательная функция доверия;

- развивающая - доверие к себе позволяет «выходить за пределы себя», не вступая с собой в противоречие [4, с. 61];

- функция самовыражения и самосовершенствования, - сущность которой заключается в самоподдержке, самоуважении, самопринятии, самоуправлении, что в свою очередь влияет на самоисправление негативных личностных черт [4, с. 61];

- аффективная - доверие предполагает акт столкновения, то есть переживания своей целостности с тем, к чему или к кому чувствуется доверие;

- креативная - нарушение баланса доверия к миру и доверия к себе в сторону доверия к себе предполагает толчок индивида к новому и возникновение риска, который обусловлен развитием потенций личности;

- прогностическая - доверие позволяет предвидеть результат взаимодействия в конкретной ситуации;

- аксиологическая - доверие играет роль регулятора в приобретении, усвоении ценностей и основы в формировании ценностно-мотивационной сферы личности [9, с. 64].

Доверие как специфический субъективный феномен имеет такие формально-динамические характеристики: меру, избирательность и парциальность. В зависимости от узнаваемости объектов и фрагментов мира окружающая среда вызывает у человека разную степень доверия, поэтому в разных жизненных ситуациях эти объекты имеют и разную значимость [22, с. 93]. Проблема заключается в нахождении оптимальной пропорции, то есть меры между доверием к себе и доверием к миру. Хотя можем предположить, что повышение уровня доверия к миру происходит на фоне уже сформированногоуровня доверия к себе, а повышение уровня доверия к себе зависит от развития творческих возможностей человека. «Возможности развития индивида, проявляющиеся тогда, когда перед ним возникают новые задачи для решения, называются потенциальными способностями» [13, с. 221]. Избирательность означает направленность личности в контексте доверия (кому или чему доверять). Парциальность предусматривает количество того, чему доверяет человек (насколько доверяет). Мера отражает интегрированную характеристику доверия (насколько глубоко доверяет человек) [9, с. 37]. 
Понимание доверия как механизма, способа, направленного на объединение человека, с одной стороны, со своими внутренними ценностями, потребностями, интересами и желаниями, то есть собственной субъектностью), а с другой - с той частью мира, с которой он собирается взаимодействовать, и позволяет квалифицировать доверие как социально-психологическое явление. Психологическим механизмом доверия выступает социальная установка, формирующаяся благодаря одновременной направленности психики человека в мир, в себя и взаимодействию двух разнонаправленных позиций социальной и личностной, сформировавшихся на основе прошлого опыта взаимодействия человека с миром. Отсюда доверие существует в интериндивидном пространстве, хотя функционирует, проявляет себя в интраиндивидном и в метандивидном пространствах. Поэтому оно изменяется, трансформируется, осуществляя познавательную функцию (связи человека с миром). Доверие - явление двуполюсное: внутреннее и социальное; многогранное образование, включающее: первичные установки, имеющие биосоциальную обусловленность (базовое доверие - недоверие к миру, потребность в безопасности); вторичные установки («вторичное доверие», направленность на мир или на себя), которые интериоризуя, превращаются в личностные установки, фиксирующиеся как качества личности.

Любой объект окружающего мира и мир в целом вызывают доверие только тогда, когда они характеризуются безопасностью (надежностью) и значимостью (ценностью) [22]. Человек, наделяя объект этими свойствами, может неоднозначно и противоречиво относиться к ним. Если значимость (ценность) объекта для индивида является большей, чем его безопасность, то взаимодействие с ним становится рискованным. В.А. Петровский, изучая психологию неадаптивной активности, писал: «Преобладание ценности риска над ценностью благоразумия выступает в форме активно-неадаптивного действия» [18, с. 121]. Это объясняется тем, что человек, доверяя себе, может не только взаимодействовать с миром, но и менять, перестраивать его. Способность доверять себе позволяет индивиду выйти за пределы ситуации, творить новую, разомкнув «постулат целесообразности», адаптивности. Поэтому рискованное поведение, неадаптивную активность можно рассматривать как проявление доверия к себе, связанного с доверием к миру. 


\section{Kravchenko Viktoria}

Если рассматривать явление доверия с точки зрения саморегуляции, то можно увидеть, что доверие, которое формируется на ранних этапах онтогенеза, постоянно изменяет свои границы по мере познания мира и включения человека в сотрудничество с ним. Когда индивид приобретает опыт взаимодействия с определенными объектами, то устанавливает с ними связь, потому что ему уже известно, насколько можно доверять им. Уровень доверия к миру соответствует привычному уровню доверия к себе. Поэтому здесь можно говорить об активности, связанной с репродуктивными видами деятельности, об относительной целостности личности. Часто у человека возникают такие потребности и ситуации (проблемные ситуации), к которым у него нет готовых форм поведения и привычных способов взаимодействия. Так как индивид всегда пытается соответствовать миру и себе, то решить несоответствие в проблемной ситуации можно двумя путями: повысить уровень доверия к себе или к миру. В первом случае (при повышении значимости, ценности собственной субъектности) возникают неадаптивные формы активности, связанные с риском, творческой инициативой. Если будет достигнут положительный результат (удовлетворение потребности путем творческой самореализации), то автоматически повышается уровень доверия к миру. Во втором случае человек пытается усилить доверие к миру (повышает значимость, ценность условий, предоставляемых миром), тогда он снижает уровень доверия к себе, а значит - и к миру [22, с. 88]. Поэтому человек и пытается всегда решать спорные ситуации определенным образом, а доверие к миру и к себе стремится к постоянному динамическому равновесию, что обеспечивает формирование жизнестойкости личности как адаптивной личностной черты.

Крайние формы выхода из равновесия приводят к патологическим последствиям: человек теряет связь с миром или отчуждается от самого себя. Отсюда мы выходим на основное методологическое положение в исследовании доверия: доверие по своей сути связано с гетеростазом, а не гомеостазом. Деятельность человека мотивирована стремлением к личностному росту, самореализации, поиску себя, к усилению доверия к себе и к миру. Это равновесие постоянно должно быть динамичным, потому что нет движения - нет развития. Речь идет о гуманитарной парадигме в психологии, основанной на изучении целостной творческой человеческой реальности [ 25, с. 440$]$. 
Уровень доверительных отношений детерминируется параметром значимости субъектов общения в отношении друг к другу. Индивид доверяет тому, кто является для него значимым, хотя последний может и не доверять первому. Значимость, однако, может выполнять роль «фильтра» в проявлении доверительных отношений, поскольку объект общения может скрывать некоторые стороны своей жизни для того, чтобы не потерять ценности в глазах другого. Поэтому значимость предусматривает прежде всего доверие, влияние друг на друга, при этом есть возможность не самораскрываться. Другим параметром доверительных отношений является безопасность, обеспечиваемая личностным уровнем взаимоотношений между людьми. Безопасность предусматривает ненанесение вреда другому, прежде всего в психологическом плане эмоциональном, моральном и тому подобное. Даже при длительных и тесных отношениях между людьми все же нельзя полностью спрогнозировать будущих поступков того, кому доверяет индивид. Поэтому доверие - это всегда риск. Единственным гарантом доверительных взаимоотношений является то, что личность относится к другой как к самой себе. Именно здесь возникает связь между доверием к себе и доверием к другому, реализуемая в аффилиации. Когда человек не боится доверять себе, относиться к себе как к самостоятельной, гармоничной личности, тогда он способен доверять другим и таким же образом относиться к ним. Однако истинная гармоничная личность всегда чувствует меру: одновременно быть открытой к миру и к самой себе [9, с. 58]. Таким образом, оптимальное соотношение доверия и недоверия - это ответ общества на вызовы современности [10, с. 61].

\section{3. Структурная модель доверия к себе}

Доверие к себе - это рефлексивный, субъективный феномен личности, позволяющий человеку занять определенную ценностную позицию в отношении к самому себе, к миру и исходя из этой позиции строить собственную жизненную стратегию. Наличие доверия к себе является важным условием субъектности личности [22, с. 139].

Доверие к себе, безусловно, связано с самосознанием личности (В. Мухина, С. Рубинштейн, В. Столин и др.), или «образом-Я» (Д. Эльконин, И. Кон, М. Лисина), или Я-концепцией (Р. Бернс, А. Маслоу, К. Роджерс и др.). Авторы, изучающие этот феномен, выделяют такие его составляющие: когнитивная (самопознание), аффективная 


\section{Kravchenko Viktoria}

(эмоционально-оценочная), поведенческая (волевая, регулятивная). Я-концепция включает в себя отражение субъектом своего уровня активности, связанного с проектированием собственной жизненной перспективы, что имеет отношение к самоценностной позиции личности, а следовательно уровню доверия к себе.

Когнитивная составляющая трактуется как убеждение личности относительно самой себя. Самооценка определяется как эмоциональное отношение к этому убеждению. Поведенческая составляющая трактуется как потенциальная поведенческая реакция, которая может быть вызвана самооценкой и образом-Я. Именно в когнитивной составляющей существуют убеждения, являющиеся фильтрами, препятствиями, ограничивают свободу человека, его представления о своих возможностях и именно от которых зависит уровень доверия к себе. Соответственно, чтобы изменить отношение к себе, нужно изменить эти представления о себе, о своих возможностях. Таким образом, суть доверия к себе заключается не только в том, что человек приписывает себе определенные качества и верит в их истинность (что сохраняет уважение к себе), сколько в том, что на основе самоатрибуций он приписывает себе определенный набор возможностей, которые также принимает на веру. При попытке сделать определенный поступок индивид решает, соответствует ли он его внутриличностным смысловым образованиям. В реальной жизни человек, может, и не рефлексирует, но всегда существует эмоциональный сигнал, оповещающий о противоречиях [22, с. 164]. Доверять себе означает не бояться что-то сделать. Доверие к себе предполагает позитивное отношение ко всему, что происходит с человеком, то есть полное принятие себя. Таким образом, степень доверия к себе определяется возможностями, которые человек видит в себе.

Однако проявление доверия к себе не всегда может осознаваться личностью, хотя в ее поступках прослеживается та или иная степень доверия к себе. Таким образом, можно предположить, что доверие к себе может проявляться как осознанное явление в результате рефлексии личности, а также как слабоотрефлексированное образование, которое проявляется в выборе определенной стратегии поведения в условиях ограниченного времени или несклонности человека к рефлексии. Здесь речь идет не о разных феноменах, а о разных уровнях одного и того же феномена, отличающегося уровнем осознанности. 
Поэтому выделяют следующие уровни доверия к себе: а) операциональный - поверхностный, слабоотрефлексированный, проявляющийся в основном при взаимодействии с внешним миром; б) рефлексивный - глубинный, основанный на самопознании, что определяет осознанность и ответственность за свою жизнь [6, с. 123]. Исследователь Н.А. Ермакова рассматривает доверие к себе как социальную установку, проявляющуюся в самопринятии, самоценности и самоблагосклонности личности [7].

Доверие к себе является сложным образованием, в структуру которого входят:

- побудительная переменная, то есть потребности, интересы, все, что инициирует активность человека (переживание «я хочу»);

- прогностическая переменная, то есть все, что связано с возможностями человека и позволяет удовлетворять его потребности (переживание «я могу»);

- ценностносмысловая переменная, актуализирующая у человека смысловые образования, связанные с оценкой ситуации и выполняющие функцию контроля (переживания «я должен») [22, с. 169];

- общественно значимая переменная, смысловые установки, соответствующие уровню целостной жизнедеятельности и имеющие общественное значение; она выступает творчеством для самого человека и сплочающим фактором для взаимодействия с другими (переживание «я буду»);

- духовная диспозиция, приводящая человека в царство абсолютной духовной свободы, где он достигает полноты переживания своего единства с Богом (Космосом) и внутренней гармонии (переживание «я принимаю») [8, с. 70].

Развитие доверия к себе и к миру проходит, безусловно, через становление зрелости личности (личностной и социальной) (К.А. Абульханова-Славская, Л.Ф. Бурлачук, Л.П. Овсянецкая, Л.Е. Орбан-Лембрик, А.В. Соловьев, Л.Д. Тодорив, И.П. Шкуратова и др.). Зрелость это состояние перехода личности от мира построения планов, поиска идеалов в мир реализации жизненных планов, перспектив, а также переход от самоопределения к самореализации [16, с. 65]. Зрелость достаточно сложное, интегрированное понятие, включающее отношение личности к себе, своей деятельности, собственному жизнетворчеству и выступающее координирующим началом активности человека 


\section{Kravchenko Viktoria}

в обществе [15, с. 107]. Саморазвитие, самоактуализация и самотрансценденция являются основой построения психологии личностной (духовной) зрелости, выступающей необходимым фактором духовности индивида. Достижение личностной зрелости проявляется в научении доверять собственным суждениям и действовать в соответствии с ними, наличии собственной, независимой от окружения системы ценностей, опосредованных сквозь призму слияния с абсолютными ценностями. Собственно доверие к себе и соответствующий уровень личностной зрелости способствуют индивиду в формировании доверительных отношений и адаптации к социальной среде, что и является показателем жизнестойкости личности.

Проведенный теоретический анализ позволяет построить модель доверия к себе, изображенную на рис. 1. «Специфической особенностью подобного конструирования является то, что модель, созданная исследователем с целью познания, соответствует реальной внутренней структуре самого психического процесса. Это означает, что исследуемый психический процесс или функция сначала конструируется в виде модели определенной деятельности, а затем актуализируется посредством специальных способов организации активности субъекта» [12, с. 117].

Сформированный уровень доверия к себе включает такие внутриличностные конструкты, как: открытость, уверенность в себе, саморегуляция, ожидание доверия от других, самоценность, самопринятие, самоуважение, аутосимпатия, обеспечивающие целостность существования прогностической («Я - могу»), ценностной («Я - должен»), общественно-значимой («Я - буду») переменных, духовной диспозиции («Я - принимаю») и аутентичность личности. Соответственно высокая самооценка служит развитию динамического равновесия доверия к себе и доверия к миру, что обеспечивает формирование жизнестойкости личности.

Недоверие к себе включает такие внутриличностные конструкты, как: самоблагосколонность, внутренняя конфликтность, самообвинение, самоуничижение, реализующие побуждающую переменную («Я - хочу») и приводящие к непониманию себя. Чрезмерное доверие к миру и одновременно недоверие к себе детерминируются низкой самооценкой личности. Чрезмерное доверие к себе и одновременно недоверие к миру зависит от завышенной самооценки. Недоверие к себе существует на операциональном уровне, а доверие к себе на рефлексивном уровне. 


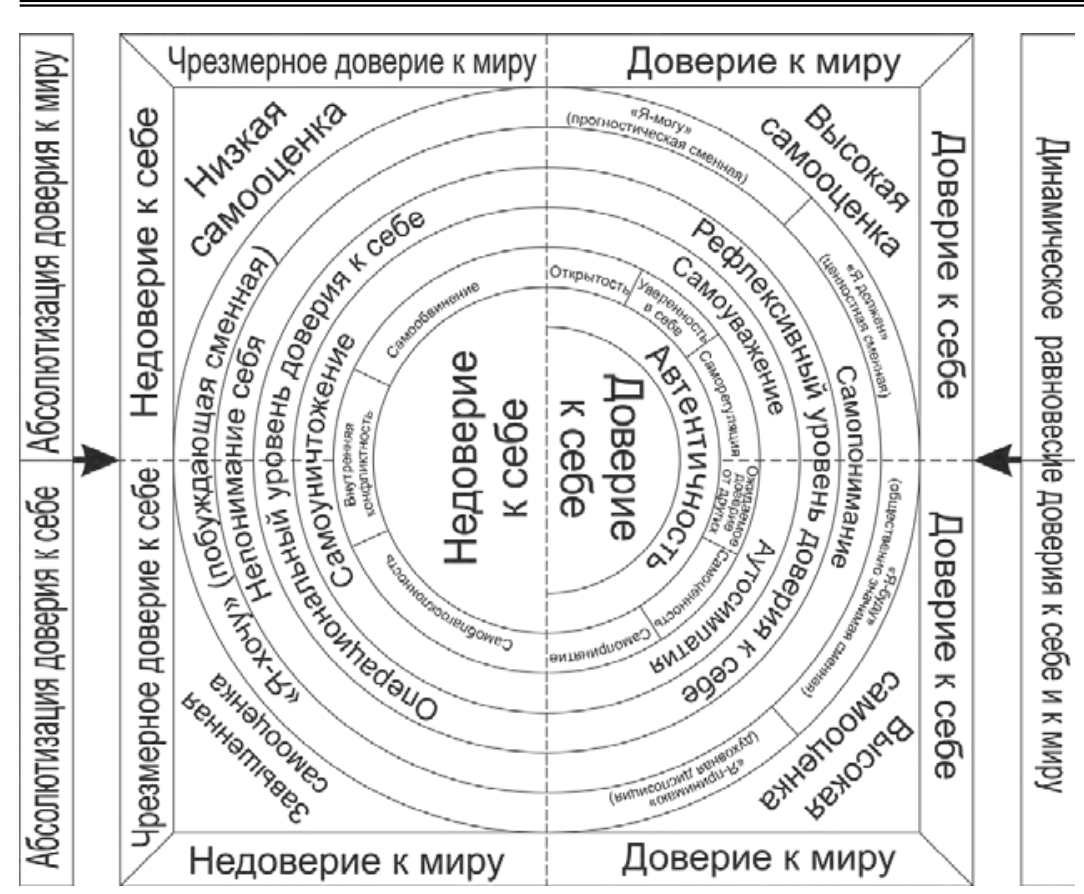

Рис. 1. Структурная модель доверия к себе

Модель доверия к себе раскрывает сущность внутренних мотивационных сил личности, позволяющих ей уверенно взаимодействовать с различными социальными группами и с легкостью строить межличностные отношения. Структурные составляющие, подающиеся в модели, отражают психологическое содержание и социально-психологические особенности доверия к себе и недоверия к себе, которые целостно объединяются в единое внутриличностное пространство индивида. Рефлексивный и операциональный уровни доверия к себе отражают степень готовности личности к продуктивным (или непродуктивным) межличностным отношениям. Динамическое равновесие доверия к себе и доверия к миру направлено на обеспечение целостности личности и развития ее подлинности. И, наоборот, абсолютизация доверия к себе и доверия к миру приводит к деструктивным тенденциям в формировании межличностных отношений и развитии Я-концепции, а также нарушению гармоничности в отношениях. 


\section{Kravchenko Viktoria}

Деформации доверительных отношений могут выражаться тремя способами. Во-первых, в чрезмерном проявлении доверия к себе, что в конечном итоге приводит к нарушениям во взаимоотношениях с другими людьми и сужает круг доверительных отношений. Во-вторых, повышенный уровень доверия к другим становится результатом снижения самооценки индивида, уровня его притязаний, повышенной тревожности и фрустрированности. В-третьих, уровень доверия к себе и уровень доверия к миру может одновременно снижаться, что называется кризисом доверия (Т.П. Скрипкина). Кроме того, существует понятие депривации доверия, что означает отсутствие потребности в установлении близких доверительных отношений с окружающими на фоне пониженного уровня доверия к себе, отношение к другим людям как к предметам. Дефицит доверия к окружающим заключается в снижении уровня доверия к другим при адекватном или завышенном уровне доверия к себе и при наличии неудовлетворенной потребности доверять $[21$, c. 560$]$. Эти явления приводят к дезадаптации личности.

Собственно примером конструктивного преодоления жизненных трудностей можно считать модель нивелирования стресса с позиций экзистенциальной парадигмы (С. Мадди). Психологическое содержание этой модели заключается в изменении стрессовых обстоятельств таким образом, чтобы они не переходили в напряжение. Человек должен найти свой способ решения проблемы, свой смысл. В таком контексте жизнестойкая позиция становится точкой отсчета, где перерабатываются стрессовые обстоятельства, где высвобождается энергия для реализации новых возможностей самореализации, предпосылкой творческого преобразования той реальности, которая вызывает страх и обеспокоенность [26, с. 295]. Продуктивность решения этих проблем полностью зависит от таких особенностей познавательной деятельности личности, как: уровень рефлексии, гибкость в восприятии жизненных событий, толерантность к неопределенности, осознание трудностей и включение их в жизненный контекст, в частности в сферу межличностного взаимодействия [26, с. 298].

Рефлексия (от лат. reflexio - отражение) - 1. Анализ собственного психического состояния. 2. Механизм взаимопонимания - осмысление субъектом того, какими средствами и почему он произвел то или иное впечатление на партнера по общению [23, с. 427]. Личностная рефлексия проявляется в процессе переосмысления индивидом своей 
внутренней сущности рассматривается как направление познания человека на себя, свой внутренний мир, как оценка своих качеств и состояний.

Существенными элементами рефлексивного процесса являются: а) рефлексивний выход - выход субъекта за пределы потока собственной жизни; б) рефлексивное поглощение - «поглощение» предыдущего образа жизни новым. Толчком, исходной точкой рефлексии чаще всего бывает несогласованность или конфликтность информации (вспомним, что все исследователи рефлексии отмечают: она возникает вследствие то ли определенного конфликта, то ли нерешаемости задачи или проблемной ситуации при кооперации деятельностей, то ли противоречивости личностно значимой информации). Такая конфликтность может быть обусловлена внутренними причинами (конфликт мотивов и деятельности личности) или внешними (противоречивость информации, получаемой по различным каналам, и собственных представлений; противоречия между позициями в общении или совместной деятельности). Операции осознания, сопоставления дают толчок для операции переосмысления, формируют информационное содержание механизму переосмысления. Результатом рефлексии являются изменения в динамической системе самосознания, представляющей собой единство постоянного и переменного компонентов в Я-концепции и самооценке личности. Далее, на основе новых представлений субъекта, подключается механизм саморегуляции, коррекции поведения согласно новому образу Я (или его составляющих). Итак, структурными компонентами механизма рефлексии выступают каналы прямой и обратной связи, мозговое представительство операций осмысления, сопоставления, переосмысления [19, с. 156].

Рефлексивный процесс (рефлексивный анализ) приводит индивида к новым знаниям о самом себе как о субъекте жизнедеятельности и позволяет обнаружить три уровня развития саморефлексии: фиксированный, заниженный и сбалансированный. Наиболее эффективным в самопознании, самоутверждении и саморазвития личности является сбалансированный уровень саморефлексии, зависящий от такого психологического феномена как доверие человека к себе. Проблема доверия к себе принадлежит к числу экзистенциальных проблем человека, поэтому именно она связана с бесчисленными выборами, которые личность должна сделать сама. Доверие к себе является относительно 


\section{Kravchenko Viktoria}

самостоятельным феноменом субъективности, который присущ внутреннему миру личности. Оно принадлежит к числу феноменов, связанных с активностью человека, способного действовать как животворный, суверенный субъект творческой активности. Поэтому доверие выступает условием существования личности как автономного субъекта активности, способного к самостоятельному выбору целей. Прогнозируя будущую активность в каждый момент времени, человек стремится соответствовать не только себе, но и миру, поэтому доверие к себе существует в единстве с доверием к миру (то есть человек всегда занимает одновременно личностную и социальную позицию) и, таким образом, обращено одновременно и в мир, и в себя. Выбирая свою деятельность, свою цель, свои поступки, человек, с одной стороны, «выходит за пределы» себя, то есть уже накопленного опыта, а с другой - обращается к смыслам, сложившимся в прошлом опыте, и опирается именно на них, то есть на их содержание. Сущность доверия к себе заключается в способности человека «выходить за пределы» себя, не вступая в противоречия с собой. Поэтому доверие к себе способствует слиянию прошлого и будущего в единый целостный акт жизнедеятельности [24, с. 245].

Гибкость восприятия жизненных событий, благодаря которой человек способен относительно легко переключаться с одной деятельности на другую, дает возможность эффективно анализировать новые, неожиданные ситуации, довольно быстро приобщаться к решению незапланированных проблем и трудностей. Толерантность к неопределенности дает возможность освободиться от привычных стереотипных форм анализа сложной ситуации, обусловливает принятие в свое сознание нового, необычного жизненного опыта [26, с. 298]. Также к признакам жизнестойкости личности относятся: выбор, планирование, терпение, вера в себя, позитивное отношение и тому подобное.

Факторы переживания экстремальной, кризисной жизненной ситуации в той или иной сфере связаны с уровнем доверия к себе: проявления негативной дезинтеграции, сопровождающиеся деструктивными изменениями личности, связанные с низким уровнем доверия к себе, положительная дезинтеграция, позволяющая облегчить переживания и преодолеть опасность, связана с высоким уровнем доверия к себе $[5$, c. 230$]$. Высокий уровень доверия к себе способствует преодолению экстремальной ситуации и личностному развитию, а низкий уро- 
вень доверия к себе приводит к возникновению посттравматического стрессового расстройства [5, с. 230]. Собственно здесь прослеживается взаимосвязь доверия к себе и жизнестойкости, что позволяет преодолевать жизненные трудности.

\section{4. Особенности и результаты эмпирического исследования доверия к себе в измерении жизнестойкости личности в юношеском возрасте}

Для определения сущности доверия в структуре жизнестойкости личности и подтверждения теоретических положений мы провели эмпирическое исследование, суть которого заключается в диагностическом срезе исследуемых по уровню доверия к себе и жизнестойкости личности. План эмпирического исследования предполагает целенаправленное выполнение следующих действий: подбор диагностического инструментария; собственно проведение тестирования; обработка и интерпретация результатов, подведение итогов.

Эмпирико-методическая модель исследования представлена следующими методами:

- теоретические методы: методы логико-психологического анализа и обобщения, конструирования, систематизации и классификации как средства диалектической логики;

- эмпирические методы: наблюдение, опрос, беседа, тестирование;

- статистические методы: корреляционный анализ Пирсона, метод углового преобразования Фишера.

Констатирующий этап исследования предусматривал сбор качественных и количественных данных, он осуществлялся путем конкретных исследовательских методик. Их подбирали по следующим критериям: объективное отражение исследуемой проблемы в диагностических методиках и их надежность и валидность.

В эмпирическом исследовании нами были использованы следующие стандартизированные методики:

1. Опросник «Самооценка жизнестойкости» (Модификация опросника Форверга на контактность Т.А. Лариной) [26, с. 500-502].

Назначение опросника заключается в определении уровня осмысленности и сформированности личностных составляющих жизнестойкости, которые проявляются в общении. Исследуемым предлагается оценить себя по 9-балльной шкале, чтобы выяснить, в какой мере 


\section{Kravchenko Viktoria}

им свойственны представленные качества (1 - лишены этого свойства, 9 - имеет свойство наибольшей степени). Обработка осуществляется соответствующим ключом, и определяется уровень осмысленности и сформированности составляющих жизнестойкости.

2. Рефлексивный опросник уровня доверия к себе Т.П. Скрипкиной [22, c. 172].

Данный опросник был использован нами с целью выявления уровня доверия к себе на основе самоотчетов испытуемых. Бланк методики предусматривает утверждение о трех сферах жизнедеятельности личности (семья, учебная (профессиональная) деятельность, сфера социальных контактов), в каждой из которых индивид может иметь разную степень доверия к себе, которую он должен оценить по такому классификатору: 3 - доверяю, 2 - частично доверяю, 1 - не доверяю. Обработка осуществляется с соответствующим ключом. Применение данного опросника позволило выяснить психологические особенности доверия к себе, что проявляется на втнуриличностном уровне и раскрывает сущность доверия к себе как субъективный феномен.

Выборка испытуемых составила 95 человек, это студенты специальности «Психология» и «Филология» (английский язык и литература) Прикарпатского национального университета имени Василия Стефаника в возрасте 18-22 лет.

Анализ полученных результатов базировался на использовании методов математической обработки психологических данных [20]. Их первичная обработка осуществлялась на основе элементов описательной статистики, в частности формул средних значений, стандартных отклонений, процентных соотношений [14].

Вторичная обработка данных основывалась на корреляционном анализе результатов по формуле коэффициента корреляции Пирсона $[2$, с. 94]. Значимость коэффициентов корреляции устанавливалась на основе учета критических значений в соответствии с объемами эмпирической выборки при уровне статистической значимости $\mathrm{p} \leq 0,01$. Для подтверждения процентного соотношения показателей методик использовался метод углового преобразования Фишера.

Расчет коэффициентов корреляции и всех необходимых промежуточных данных осуществлялся с помощью компьютерной обработки, которая обслуживалась пакетом программ EXCEL, STATISTIKA. 
Проанализируем результаты методики «Самооценка жизнестойкости», которые подаются на рис. 2. Согласно результатам мы получили, что у $0 \%$ испытуемых низкий уровень осмысленности и сформированности жизнестойкости, у $8 \%$ испытуемых - средняя степень пораженности жизнестойкости, 32\% исследуемых определяют жизнестойкость как характерную черту, $58 \%$ исследуемых активно

проявляют жизнестойкость и 2\% испытуемых в полной мере проявляют исследуемое свойство.

Заметно, что у большинства исследуемых активно проявляется жизнестойкость, что побуждает и направляет индивида на сотрудничество, обеспечивает реализацию способности самостоятельно находить пути решения проблем. Это объясняется особенностями адаптации в новой социальной среде, изменением социальной ситуации развития, выходом в полноценную самостоятельную взрослую жизнь. Однако в целом по выборке мы можем заметить более или менее сформированную такую личностную черту как жизнестойкость и даже осмысленную студентами на данном этапе их жизни.

Согласно рефлексивному опроснику доверия к себе у $85 \%$ исследуемых высокий уровень доверия к себе, у 15\% испытуемых - средний уровень доверия к себе и у $0 \%$ испытуемых - низкий уровень (см. рис. 3).

Заметно, что большинство исследуемых данной выборки доверяют себе, а следовательно осознают свои возможности и особенности, саморефлексуют и проявляют самопонимание. Несомненно, это свя- 


\section{Kravchenko Viktoria}

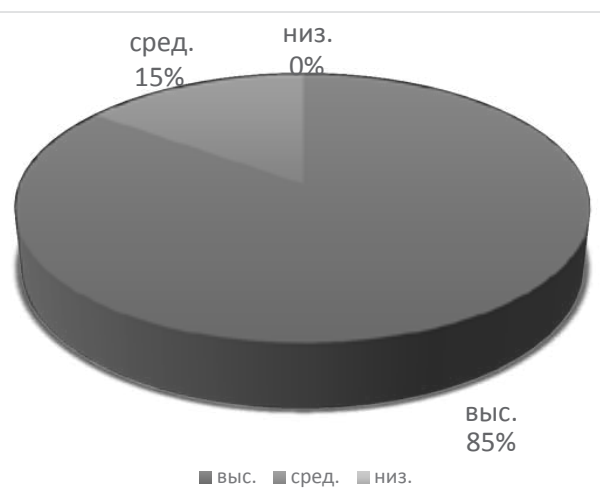

Рис. 3. Результаты опросника
доверия к себе

зано с особенностями самооценки.

Во всех сферах жизнедеятельности, которые представлены в диагностической методике, исследуемые проявляют доверие к себе, в частности в сфере семьи, - 91\% исследуемых имеет высокий уровень, $8 \%$ испытуемых - средний и $0 \%$ испытуемых - низкий уровень; в профессиональной сфере (учебной деятельности) - 77\% исследуемых имеют высокий уровень, 23\% испытуемых - средний и $0 \%$ испытуемых - низкий уровень; в сфере социальных контактов $-70 \%$ исследуемых имеют высокий уровень, $30 \%$ испытуемых - средний и 0\% испытуемых - низкий уровень, что изображено на рис. 4.

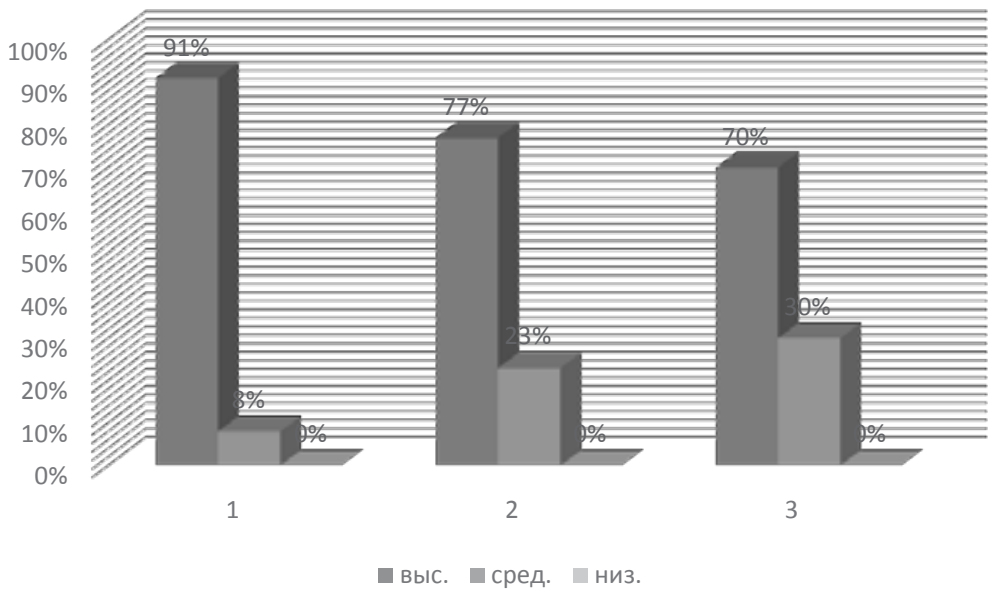

Рис. 4. Показатели доверия к себе в разных сферах жизнедеятельности

Примечание. 1 - сфера семьи, 2 - профессиональная сфера (учебная деятельность), 3 - сфера социальных контактов. 
Для уточнения результатов сравним результаты методик в двух группах испытуемых: у будущих психологов (68 человек) и будущих филологов (27 человек).

По методике «Самооценка жизнестойкости» мы получили следующие показатели: у студентов специальности «Психология» наибольший процент (60\% испытуемых) по уровню «активно проявляется жизнестойкость», для $29 \%$ испытуемых - жизнестойкость является характерной чертой, 9\% исследуемых проявляют средний уровень жизнестойкости, $0 \%$ испытуемых - низкий уровень и $2 \%$ испытуемых очень высокий уровень жизнестойкости (см. рис. 5). У студентов специальности «Филология» наибольший процент (52\% испытуемых) по уровню «активно проявляется жизнестойкость», для $37 \%$ испытуемых - жизнестойкость является для них характерной чертой, 7\% исследуемых проявляет средний уровень жизнестойкости, $0 \%$ испытуемых - низкий уровень и 4\% испытуемых - очень высокий уровень.

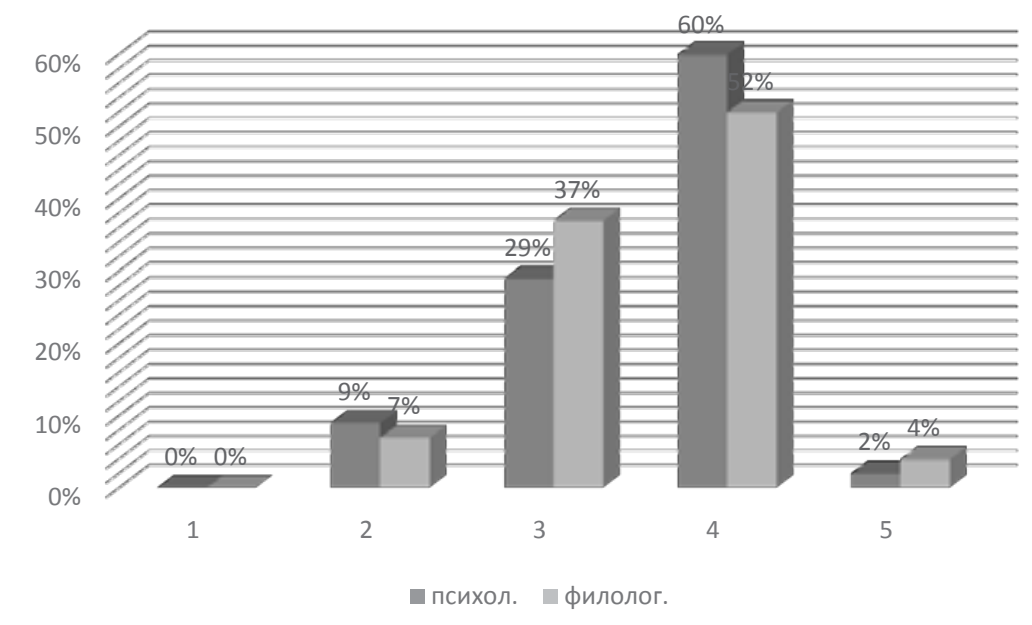

\section{Рис. 5. Показатели жизнестойкости студентов специальностей «Психология» и «Филология»}

Примечание. 1 - низкий уровень осмысленности и сформированности составляющих жизнестойкости, 2 - средняя степень выраженности жизнестойкости, 3 - жизнестойкость является характерной чертой, 4 - активно проявляется жизнестойкость, 5 - свойство присуще в полной мере. 


\section{Kravchenko Viktoria}

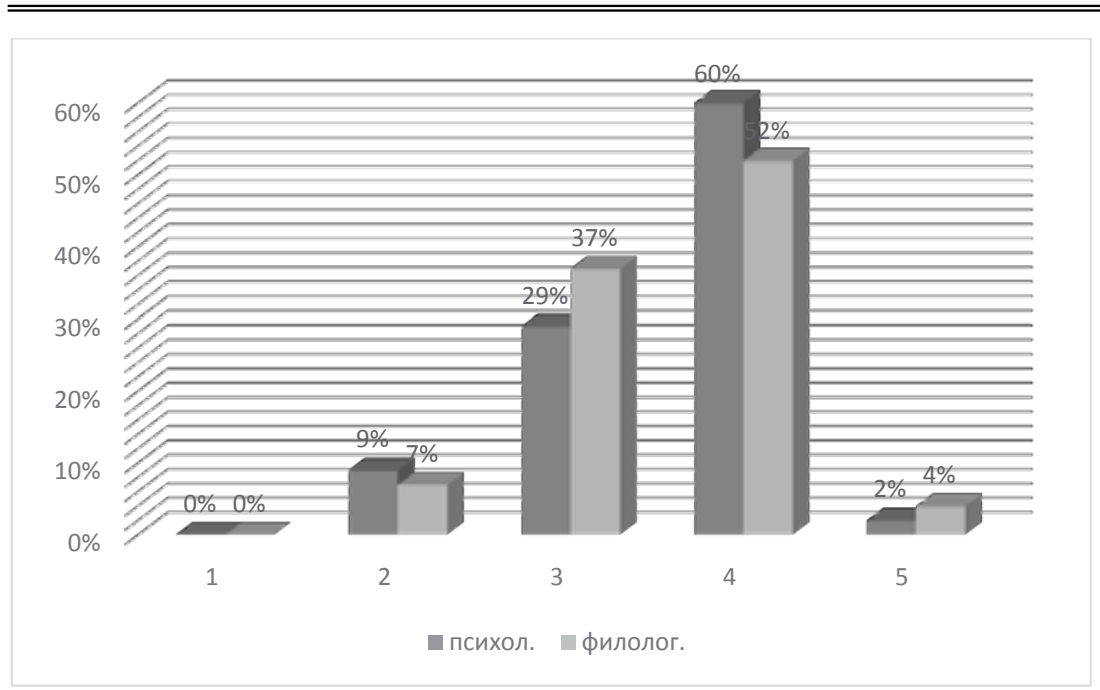

\section{Рис. 6. Уровень доверия к себе у студентов специальностей «Психология» и «Филология»}

Согласно опроснику доверия к себе у подавляющего большинства всех студентов высокий уровень доверия к себе: у $88 \%$ студентов специальности «Психология» и 78\% исследуемых специальности «Филология» высокий уровень проявления доверия к себе; у 12\% студентов специальности«Психология» и $22 \%$ исследуемых специальности «Филология» - средний уровень проявления доверия к себе, и у студентов обеих специальностей отсутствует низкий уровень доверия к себе (см. рис. 6).

Поскольку в двух группах испытуемых было неровное количество лиц, то для статистической достоверности был использован метод углового преобразования Фишера. Для этого мы выдвинули гипотезы:

Н0 - нулевая гипотеза, сущность которой заключается в том, что различий в показателях доверия к себе на разных уровнях проявления (высокий, средний, низкий) и жизнестойкости у студентов специальностей «Психология» и «Филология» нет;

Н1 - рабочая гипотеза, сущность которой заключается в том, что проявление доверия к себе на разных уровнях и жизнестойкости у студентов специальностей «Психология» и «Филология» отличается. 
Согласно угловому преобразованию Фишера мы получили $\varphi 1=0$, $\varphi 2=0,32, \varphi 3=0,75, \varphi 4=071, \varphi 5=0,52$, что не является больше критических значений данной выборки испытуемых на статистически значимом уровне $\mathrm{p} \geq 0,05$ (см. табл. 1). Поэтому мы принимаем нулевую гипотезу.

Согласно угловому преобразованию Фишера о доверии к себе мы получили $\varphi 1=1,18, \varphi 2=1,18, \varphi 3=0$, не является больше критических значений данной выборки испытуемых на статистически значимом уровне $\mathrm{p} \geq 0,05$ (см. табл. 2). Поэтому мы принимаем нулевую гипотезу.

Итак, выбор специальности, место учебы, специфика учебной ситуации (профиль обучения) в нашем исследовании не являются определяющими факторами формирования жизнестойкости и доверия к себе. Значимыми являются сама ситуация развития юных лиц, связанная с возрастными особенностями, и само изменение социальной среды (они стали студентами университета).

Однако нас интересует вопрос взаимосвязи доверия к себе и жизнестойкости. Для этого мы использовали корреляционный анализ

Таблица 1

\section{Сравнение показателей жизнестойкости} между студентами разных специальностей (по $\varphi$-Фишеру)

\begin{tabular}{|c|c|c|c|c|c|c|c|}
\hline & \multicolumn{2}{|c|}{$N=68$ (nc.) } & \multicolumn{2}{|c|}{$N=27$ (ин.) } & \multirow{2}{*}{$\varphi_{i}$} & \multirow[b]{2}{*}{$p$} & \multirow{2}{*}{$\boldsymbol{H}$} \\
\hline & $\%$ & $\varphi_{p a d .}$ & $\%$ & $\varphi_{p a d .}$ & & & \\
\hline 1. & $0 \%$ & 0 & $0 \%$ & 0 & 0 & $\geq 0,05$ & $\mathrm{HO}$ \\
\hline 2. & $9 \%$ & 0,609 & $7 \%$ & 0,536 & $\mathbf{0 , 3 2}$ & $\geq 0,05$ & $\mathrm{Ho}$ \\
\hline 3. & $29 \%$ & 1,137 & $37 \%$ & 1,308 & $\mathbf{0 , 7 5}$ & $\geq 0,05$ & $\mathrm{H} 0$ \\
\hline 4. & $60 \%$ & 1,772 & $52 \%$ & 1,611 & 0,71 & $\geq 0,05$ & $\mathrm{HO}$ \\
\hline 5. & $2 \%$ & 0,284 & $4 \%$ & 0,403 & $\mathbf{0 , 5 2}$ & $\geq 0,05$ & $\mathrm{H} 0$ \\
\hline
\end{tabular}

Таблица 2

Сравнение показателей доверия к себе между студентами разных специальностей (по $\varphi$-Фишеру)

\begin{tabular}{|c|c|c|c|c|c|c|c|}
\hline & \multicolumn{2}{|c|}{$N=68(n c)}$. & \multicolumn{2}{|c|}{$N=27$ (ин.) } & \multirow[b]{2}{*}{$\varphi_{i}$} & \multirow[b]{2}{*}{$p$} & \multirow{2}{*}{$\boldsymbol{H}$} \\
\hline & $\%$ & $\varphi_{\text {pad. }}$ & $\%$ & $\varphi_{\text {pad. }}$ & & & \\
\hline Выс. & $88 \%$ & 2,434 & $78 \%$ & 2,165 & 1,18 & $\geq 0,05$ & $\mathrm{H} 0$ \\
\hline Сред. & $12 \%$ & 0,707 & $22 \%$ & 0,976 & 1,18 & $\geq 0,05$ & $\mathrm{H} 0$ \\
\hline Низ. & $0 \%$ & 0 & $0 \%$ & 0 & 0 & $\geq 0,05$ & H0 \\
\hline
\end{tabular}




\section{Kravchenko Viktoria}

Пирсона. Согласно ему $r=0,4$ при $p \geq 0,01$. Это указывает на невысокую положительную нелинейную связь между исследуемыми феноменами, подтверждая мнение о том, что доверие к себе непостредственно связано с жизнестойкостью личности и является ее составляющей, что и нужно было нам доказать.

\section{5. Ресурсы актуализации развития доверия и жизнестойкости в период юности}

Высокий уровень жизнестойкости дает возможность поддерживать оптимальный уровень психологического комфорта, чувствовать безопасность, стабильность и защищенность при постановке жизненных задач; сохранять свое психологическое здоровье, поддерживать веру в себя и доверие к окружающим при их реализации [26, с. 419]. Формирование оптимального уровня доверия к себе зависит от того, насколько человек способен относиться к своей субъектности как к ценности и одновременно соответствовать миру, в котором он живет. Индивид будет доверять себе самому, если познает себя и свои возможности до конца. Однако человек не может познать себя до конца, поэтому в процессе жизни он снова и снова испытывает себя с целью проверки собственных возможностей, в существование которых он должен поверить. Именно с этой целью доверие к себе является необходимым в жизни.

Доверие к себе относится к явлениям, связанным с активностью личности, способной действовать как суверенный субъект. Все это можно назвать самоорганизацией личности, которая означает: в первую очередь формирование у человека доверия к себе, сущность которого заключается в способности самостоятельно ставить цели и действовать в соответствии с ними (сохраняя адекватную критическую позицию по отношению к самому себе), в способности предвидеть результаты действий до их выполнения, самостоятельно строить стратегию достижения цели (в соответствии с внутриличностными смыслами), уметь соотносить потребности с возможностями их реализации в определенной ситуации и с интериоризированными личностью социокультурными ориентирами (смыслами). Оптимальный уровень доверия к себе в конечном итоге предполагает овладение умением самоорганизации своей жизни. Все это возможно благодаря тому, что личность способна относиться к себе как к ценности. Причем, выби- 
рая стратегию поведения, соотвествовать миру, в котором живет, и одновременно соотвествовать самой себе, своим ценностным представлениям о себе.

Онтологически проблема доверия в юношеском возрасте прослеживается еще с периода раннего детства. Устраивая свою жизнь, человек, сам того не осознавая, подчиняется «сценарию жизни - подсознательному жизненному плану, с помощью которого люди структурируют свое время и определяют свою судьбу», лишая себя свободы выбора [3, с. 184]. При соблюдении бессознательного, сформированного еще в детстве жизненного сценария личность ежедневно, принимая решения, рационально мотивирует их, чтобы оправдать свое запрограммированное поведение. Сценарий жизни, который приводит как к успехам, так и к неудачам, всегда приносит поглаживание. В этом и заключается главная причина принятия детских решений во взрослой жизни, ведь человек всегда хочет внимания. И только при доминирующем эго-состоянии Взрослого индивид способен сочетать в себе эго-состояние Отца (как заботливую и воспитывающую часть своей личности) и эго-состояние Ребенка (как спонтанную, эмоциональную и искреннюю часть личности). Если человек не придерживается стереотипной линии поведения, а использует всю многогранность своей личности, то можно утверждать, что он встал на путь реализации своего потенциала, проявления подлинности. Изучение самого себя, своих интересов, желаний, ценностей, склонностей является основанием для построения каждый раз новых отношений с окружающими и доверия им.

Принятие ребенком решения, которое осуществляется под воздействием внешней среды, прежде всего семьи, не может недооцениваться. Семья, как один из первых и важнейших институтов социализации личности, способна заложить у будущей личности как пагубный сценарий жизни, так и «фундамент» человека, который ставил бы перед собой цели, аутентичные достигнутому, осмысленному и пережитому опыту. Только во втором случае сущность человека будет рассматриваться как аутентичная и связываться с его способностью создавать принципиально новые возможности для собственного развития. Это лучше всего проявляется в дружеских и любовных отношениях, что является ресурсной зоной развития доверия в юношеском возрасте. 


\section{Kravchenko Viktoria}

Дружба основана на справедливости, она не требует от человека невозможного, потому что обращена к его реальному Я, которое по-настоящему может реализовать свою интегральность. От друга ждут понимания, другу дают понимание. «Зона понимания» для человека находится прежде всего в дружеских отношениях. И если данный уровень не удовлетворяет потребность в аффилиации, то можно говорить о «потере» для личности (разочарование и фрустрация), что вытекает из переживания ею невозможности воплощения собственной екзистенциальности. Многим людям достаточно пережить это раз, чтобы потом остерегаться людей всю жизнь. Для дружбы не имеет большого значения частота и продолжительность контактов с настоящим другом. Важна только существенная сторона встреч. Встреча - это точка роста сил Я, это момент переживания энергии собственной интегрированности, реальности бытия собственного Я. Именно встреча дает возможность пережить свою позицию как действительно существующую, реальную, которая может задать направление в движении по жизни, что реализуется как индивидуальная судьба. Во время встречи время приобретает особый экзистенциальный смысл - все, что происходит, имеет реальный смысл, а все, что проходит между встречами, может вовсе не иметь никакого значения. Во встречах всегда заложена готовность к продолжению, к обновлению. Если же с ней не связано это переживание, то это означает, что дружбе пришел конец. Разговор с другом позволяет осознать, кем Я есть на самом деле. Человек может быть сам собой только в соответствии с тем, что он сам о себе думает. Познавая друга, человек познает себя. Именно друг своим присутствием в жизни будто гарантирует независимое существование Я. Одной из особенностей дружбы является умение прощать. Это проявление безграничного доверия к силе Я другого человека осуществлять свою интегральность, воплощение в жизнь.

В развитии отношений в юношеском возрасте доверие к ровеснику реализуется в сфере интимно-личностного общения, главная цель которого - понимание и самораскрытие. Сложным и неоднозначным является вопрос о взаимности самораскрытия. Общее правило взаимности утверждает, что открытость и проявление доверия в большей степени вызывают у партнера соответствующий отзыв (откровенность за откровенность), повышая тем самым общий уровень интимности отношений. С одной стороны, этот феномен объясняется так, что 
доверие, будучи приятным, отрадным, вызывает симпатию, влечение к тому, кто его совершил, и таким образом знаком приверженности служит взаимная откровенность. С другой - в духе теории справедливости, поскольку любая откровенность считается ценной, человек, выслушав чужую исповедь, чувствует себя обязанным поступать так же, независимо от своего отношения к собеседнику. А еще с другой взаимность самораскрытия связывается с механизмами подражания и подкрепления: откровенность служит положительным стимулом, что в свою очередь стимулирует первого субъекта к продолжению интимной беседы. Однако самораскрытие может иметь различный личностный смысл. В доверительном общении со взрослыми важным становится не только познание своего реального Я, но и познание себя с точки зрения своих жизненных перспектив, своего будущего. Доверие к близкому взрослому не всегда базируется на глубоком самораскрытии, так как существует дистанция, обусловленная статусом взрослого и юноши. Она проявляется только в каких-то сложных ситуациях и связана не с интимностью (секретностью) информации, а со значимостью того, что сообщает юноша взрослому. Юношеская дружба с лицом противоположного пола часто перерастает во влюбленность, любовь.

Любовь раскрывается человеку через доверие, интегрирующее его внутреннее бытие, объединяет в единую связь с другим человеком, целостно отражает переживания к нему. Благодаря доверию личность может сопоставлять себя с другой личностью, что позволяет целостно воспринимать свое бытие. На фоне любовных отношений доверие выступает мощным фактором формирования этих отношений и основой для выражения своих чувств.

Еще одним ресурсом актуализации развития доверия в жизни молодого человека является поиск подлинности. Выделяют четыре экзистенциальные условия-шаги [17, с. 91]. Первым и основным условием является осознание, или открытость опыту - внутреннему и внешнему, или чувствительность к самому себе, способность слушать самого себя. Человек слушает себя и переживает себя сквозь призму мира. Каждое внешнее событие вызывает у него определенную реакцию, не всегда желанную. Однако то, что он чувствовать «не должен», не следует вытеснять, проецировать себя на субъект только при условии активной реакции на внешний мир. Вытеснение же собствен- 


\section{Kravchenko Viktoria}

ных чувств ведет к потере чувства Я, а также к ощущению бессилия, неуверенности, внутренней пустоты, отсутствия смысла.

Для того, чтобы стать свободным по отношению к этим чувствам и уметь принимать ответственность за них, человеку необходимо сделать второй шаг, а именно: приобрести доверие к самому себе, или же внутреннее согласие со своими чувствами. Это означает саморефлексировать.

Третьим шагом в нахождении подлинности является приобретение умения принимать решения. На этапе принятия решения человек перебирает возможные варианты действий, советуясь со своим внутренним голосом: он удерживается в «фокусе себя». Правильное решение - это всегда внутренне оправданное решение. Доверие к себе лежит в основе свободного выбора, будучи единственным его «достоверным» критерием. И человек постоянно выбирает, идти ли ему по этому пути или отказаться от него.

Четвертый шаг к осознанной подлинности - это способность реализовывать действие даже в ситуации, когда «внутренняя очевидность» перестает быть доступной. Это такое доверие к себе, которое позволяет действовать по собственной воле, придерживаться собственного выбора. Человек не может постоянно удерживаться в «фокусе себя», но если он верит в то, что выбранный путь является верным, если принимает на себя ответственность, у него больше шансов оказаться в «фокусе себя». Осознание подлинности не следует воспринимать как простую последовательность шагов, поскольку оно происходит в потоке целостного бытия, в свернутом виде включает в себя все эти этапы, которые в онтогенезе формируются отдельно, но со временем интегрируются, создавая целостность, которая становится основным качеством бытия.

Доверие к себе, как и доверие к другим, не может быть одинаковым во всех ситуациях общения. В одних сферах жизнедеятельности у человека может быть сформирована установка на доверие к себе, а в других - нет. Все зависит от того, как оценивает свои возможности человек, насколько адекватны его самооценка и уровень притязаний, их соотношение и насколько удовлетворены его базовые потребности (потребность в достижении, потребность в любви, в аффилиации и, наконец, в доверии). Эффективным способом приобретения доверия между людьми является межличностный диалог, который создает оптимальные условия для реального влияния на развитие личности, так как личностный рост обязательно предполагает свободу саморе- 
ализации. Это верность себе, вера в себя и доверие к себе, освобождение от страха «несоответствия» каким-то заданным извне нормам, от защит, стереотипов. Принятие своей свободы означает и признание ответственности за себя и свою свободу. Межличностный диалог характеризуется также равноправием собеседников и личностным контактом между собеседниками на основе эмпатии и взаимопонимания. Равноправие предполагает взаимное признание свободы.

Доверие является условием взаимодействия «человек-человек». Другими словами можно сказать, что доверие является главным исходным условием диалогичности в общении. Оно существует как субъективная социальная позиция в отношении к другому во внутриличностном пространстве, и ее существование «выносится» наружу, порождая изменения в межличностных отношениях. Однако этот процесс является встречным, поскольку существующий уровень доверия может меняться, усиливаться, ослабляться или вообще исчезать. Причем взаимодействующие субъекты могут об этом не знать или неправильно интерпретировать. Поэтому, если в любом акте общения или взаимодействия людей существует определенное количество доверия, то количество или мера является динамической характеристикой, определяющей качественную сторону процесса взаимодействия, или диалогичности. В связи с этим выделяют два вида диалогических отношений. Это - истинный диалог, который выступает творческим смыслообразующим процессом, и квазидиалог, который имеет диалогичность только по форме и в котором нарушается симметричность отношений.

Полное взаимное доверие на практике возникает очень редко, но именно оно выступает идеальной моделью диалога (что более всего проявляется в дружбе и любви). Однако и в истинном диалоге можно рассматривать различные модальности отношений между людьми. Так, универсальным условием возникновения доверия является атрибуция значимости и безопасности объекта доверия. Однако объектом доверия может быть как другой человек, так и информация, которую он передает. Причем они могут не совпадать. Индивид может доверять информации, которую передает другой, и не доверять человеку, который ее передает. И, наоборот, доверять человеку, но не доверять информации, которую он передает. В связи с этим идеальная модель диалоговых отношений будет иметь место только тогда, когда уровень доверия к информации совпадает с уровнем доверия к личности, от которой она получена. 


\section{Kravchenko Viktoria}

При этом значимость информации должна совпадать по уровню у обоих взаимодействующих субъектов. Именно поэтому доверие и доверительное общение полностью не совпадают по своей сути. Таким образом, истинный диалог предполагает симметричность (конгруэнтность) таких переменных: 1) взаимность доверительных установок в отношении друг к другу 2) взаимное доверие к передаваемой информации; 3) взаимная значимость этой информации для обоих взаимодействующих субъектов [21, с. 556]. Нарушение хотя бы одной переменной приводит к квазидиалогу. Доверие выступает во взаимодействии тем моментом, который придает коммуникативному акту внутренне-смысловой статус общения. То есть соответствующая мера доверия в актах коммуникации позволяет осуществить переход к субъект-объектного образа коммуникации в субъект-субъектному общению, которое реализуется через идентификацию, эмпатию и рефлексию.

На феноменологическом уровне это можно представить так: регулируя свое поведение, прогнозируя его, человек всегда определенным образом соотносит свои возможности (в той мере, в которой он их осознает, т.е. рефлексирует) с тем, насколько важны, значимы для него требования и условия, исходящие из внешней деятельности. Поэтому понять сущность доверия к себе можно только опираясь на единую онтологию «человек-мир». Без доверия к себе невозможен творческий, то есть животворный, характер деятельности, невозможно самопроектирование будущего, поскольку оно предусматривает прежде всего отношение к себе как к ценности. В результате именно доверие к себе является одним из механизмов, моделирующим эффект сбалансированности уровня саморефлексии [9, с. 165].

\section{6. Выводы}

Доверие является составляющей жизнестойкости личности, которая формируется из равновесия доверия к миру и доверия к себе. Явления доверия и жизнестойкости пересекаются на грани рискованного поведения, что позволяет реализовать свой внутренний потенциал для преодоление трудностей и создает новые перспективы развития (поиск самого себя, себя нового и непознанного). Существует связь доверия к себе и жизнестойкости: высокий уровень доверия к себе способствует преодолению экстремальной ситуации и личностному развитию, а низкий уровень приводит к развитию дезадаптации. Рефлексия, гибкость, 
толерантность к неопределенности выступают факторами развития как доверия к себе, так и жизнестойкости личности. Доверие к себе и проявление жизнестойкости личности являются показателями зрелости личности и самосознания. Ресурсными зонами в формировании доверительных отношений и жизнестойкости в юношеском возрасте являются: активность и познавательная деятельность отдельно взятого индивида, жизненный опыт, находящихся в континууме «родительский сценарий - саморефлексия», дружеские и любовные отношения, поиск подлинности и развитие диалогичности. Дальнейшие исследования направлены на исследование доверия к другим.

\section{Список литературы:}

1. Александрова Л.А. К концепции жизнестойкости в психологии. Сибирская психология сегодня : сб. научн. трудов. Кемерово, 2004. Вып. 2. С. 82-90.

2. Белей М.Д., Тодорів Л.Д. Основи діагностичної психології. ІваноФранківськ, 2008. 296 с.

3. Берн Э. Игры, в которые играют люди. Психология человеческих взаимоотношений; люди, которые играют в игры. Психология человеческой судьбы. Москва, 1988. 400 с.

4. Ворожбит С. Соціально-психологічні функції явища довіри. Соціальна психологія. 2001. № 1. С. 56-63.

5. Достовалов С. Изменения доверия к себе в межличностных отношениях в условиях экстремальной ситуации. Общение-2006: на пути к энциклопедическому знанию: Материалы конференции (19-21 октября 2006 г.). Психологический институт РАО. Москва, 2006. С. 228-234.

6. Достовалов С. Операциональный и рефлексивный уровни доверия к себе. Материалы Сибирского психологического форума [«Методологические проблемы современной психологии: иллюзии и реальность»] (16-18 сентября 2004 г.). Томск, 2004. С. 121-126.

7. Срмакова Н.О. Психологічні особливості становлення довіри до себе в юнацькому віці: дис. ... канд. психол. наук: 19.00.07. Київ, 2008. 206 с.

8. Карпенко 3.С. Аксіопсихологія особистості. Київ, 1998. 216 с.

9. Кравченко В.Ю. Довіра як прояв афіліативної потреби особистості в юнацькому віці: дис. ... канд. психол. наук: 19.00.05. Київ, 2009. 238 с.

10. Купрейченко А.Б. Психология доверия и недоверия. Москва, 2008. 571 с.

11. Мадди С.Р. Теории личности: стравнительный анализ. СПб., 2002. 539 с.

12. Максименко С.Д. Генеза здійснення особистості. Київ, 2006. 240 с.

13. Міщиха Л.П. Психологія творчості. Івано-Франківськ, 2007. 448 с.

14. Наследов А.Д. Математические методы психологического исследования. Анализ и интерпретация данных: учебное пособие. СПб., 2004. 392 с.

15. Овсянецька Л.П. До питання про психологічні критерії зрілої особистості. Актуальні проблеми психології. Т. 1. Соціальна психологія. Психологія управління. Організаційна психологія. Київ, 2001. Ч. 2. С. 105-110. 


\section{Kravchenko Viktoria}

16. Орбан-Лембрик Л.Е. Соціальна психологія. [у 2 кн.]. Київ, 2004. Книга 1. Соціальна психологія особистості і спілкування. 2004. 558 с.

17. Осин Е. Аутентичность. Экзистенциальная традиция: Философия, психология, психотерапия. Журнал Восточно-Европейской ассоџиации экзистенииальной терапии. Ростов-на-Дону, 2004. Вып. 2. (5). С. 88-93.

18. Петровский В.А. Личность в психологии: парадигма субъектности. Ростов-на-Дону, 1996. 512 с.

19. Савчин I.М. Системна рефлексія як механізм саморегуляції життєдіяльності особистості. Збірник наукових пращь: філософія, соџіологія, психологія. Івано-Франківськ, 2003. Вип. 8. Ч. 1. 236 с.

20. Сидоренко Е.В. Методы математической обработки в психологии. СПб., 2004. 350 с.

21. Скрипкина Т.П. Деформация доверительных отношений как фактор дезадаптации личности. Общение-2006: на пути к энциклопедический знанию: Материалы конференции (19-21 октября 2006 г.). Психологический институт РАО. Москва, 2006. С. 555-561.

22. Скрипкина Т.П. Психология доверия. Москва, 2000. 264 с.

23. Шапар В.Б. Психологічний тлумачний словник. Харків, 2004. 640 с.

24. Шеремета В.Ю. Психологічний аналіз впливу саморефлексії на формування довіри до себе. Збірник наукових праць: філософія, соціологія, психологія. Івано-Франківськ, 2007. Вип. 12. Ч. 1. С. 242-248.

25. Шеремета В.Ю. Соціальні функції довіри. Проблеми загальної та педагогічної психології. Збірник наукових праць Інституту психології ім. Г.С. Костюка АПН України. Т. ІХ. Ч. 1. Київ, 2007. С. 437-444.

26. Як будувати власне майбутнє: життєві завдання особистості [ред. Т.М. Титаренко]. Кіровоград, 2012. 512 с.

\section{References:}

1. Aleksandrova L.A. (2004). Kontseptsii zhiznestoikosti v psihologii [Concepts of resilience in psychology]. Sibirskaia psihologiia segodnia: sb. nauchn. trudov. Kemerovo: Kuzbassvuzizdat. - Ed. 2, pp. 82-90. (in Russian)

2. Belei M.D., Todoriv L.D. (2008). Osnovy diahnostychnoi psyhologii [Fundamentals of diagnostic psychology]. Ivano-Frankivsk: Tipovit, p. 296. (in Ukrainian)

3. Bern E. (1988). Igry, v kotoryie igraiyt liudi. Psihologiia chelovecheskih vzaimootnoshenii; liudi, kotoryie igraiyt v igry. Psikhologiia chelovecheskoi sudby [Games People Play. Psychology of human relationships; people who play games. Psychology of human destiny]. Moscow: Progress, p. 400. (in Russian)

4. Vorozhbyt S. (2001). Sotsialno-psykholohichni funktsii yavyshcha doviry. Sotsialna psyhologia, № 1, pp. 56-63.

5. Dostovalov S. (2006). Izmeneniia doveriia $\mathrm{k}$ sebe $\mathrm{v}$ mezhlichnostnyh otnosheniiah $\mathrm{v}$ usloviiah ekstremalnoi situatsi. [Changes in trust in interpersonal relationships in a extreme situation]. Obshchenie-2006: na puti kentsiklopedicheskomu znaniiu: Materialy konferentsii (19-21oktiabria 2006 g.). Psikhologicheski institut RAO. Moscow: Akademiia imidzheologii, pp. 228-234. (in Russian) 
6. Dostovalov S. (2004). Operatsionalnyi i refleksivnyi urovni doveriia $\mathrm{k}$ sebe. [Operational and reflexive levels of self-confidence]. Materialy Sibirskogo psikhologicheskogo foruma [«Metodologicheskiie problemy sovremennoi psikhologii: illiuzi i realnost»], 16-18 sentiabria 2004. Tomskii gosudarstvennyi universitet. Tomsk, pp. 121-126. (in Russian)

7. Yermakova N.O. (2008). Psykholohichni osoblyvosti stanovlennia doviry do sebe v yunatskomu vitsi: dys. kand. psykhol. nauk: 19.00.07 [Psychological peculiarities of establishing of self-confidence in adolescence: dissertation of candidate of psychological sciences 19.00.07]. Yermakova Nataliia Oleksandrivna. Kyiv, p. 206. (in Ukrainian)

8. Karpenko Z.S. (1998). Aksipsyholohiia osobystosti [Axiopsychology of personality]. Kyiv: TOV «Mizhnar. fin. Agentsiia», p. 216. (in Ukrainian)

9. Kravchenko V.Yu. (2009). Dovira yak proiav afiliatyvnoi potreby osobystosti v yunatskomu vitsi: dys. kand. psykhol. nauk: 19.00.05 [Trust as a manifestation of the affiliated need of an individual in adolescence: dissertation of candidate of psychological sciences 19.00.05]. Kravchenko Viktoriia Yuriivna. Kyiv, p. 238. (in Ukrainian)

10. Kupreichenko A.B. (2008). Psikhologiia doveriia i nedoveriia [Psychology of trust and distrust]. Moscow: Izdatelstvo «Institut psihologii RAN», p. 571. (in Russian)

11. Maddi S.R. (2002). Teorii lichnosti: sravnitelnyi analiz [Theory of personality: comparative analysis]. S.R. Maddi. SPb.: Rech, p. 539. (in Russian)

12. Maksymenko S.D. (2006). Heneza zdiisnennia osobystosti [Genesis of personality]. Kyiv: Vydavnytstvo TOV"KMM", p. 240. (in Ukrainian)

13. Mishchykha L.P. (2007). Psykholohiia tvorchosti. Navchalnyi posibnyk [Psychology of art]. L.P. Mishchykha. - Ivano-Frankivsk: Hostynets, p. 448. (in Ukrainian)

14. Nasledov A.D. (2004). Matematicheskiie metody psihologicheskogo issledovaniia. Analiz i interpretatsiia dannyh: uchebnoe posobiie [Mathematical methods of psychological research. Analysis and interpretation of data: tutorial]. $\mathrm{SPb} .:$ Rech, p. 392. (in Russian)

15. Ovsianetska L.P. (2001). Do pytannia pro psykholohichni kryterii zriloi osobystosti [About questions of psychological criteria of mature person]. Aktualni problem psyholohii, vol. 1. Kyiv: Instytut psykholohii im. Kostiuka APN Ukrainy, Ch. 2, pp. 105-110. (in Ukrainian)

16. Orban-Lembryk L.E. (2004). Sotsialna psyholohiia [Social psychology] [2 books.]. Kyiv: Lybid, Book 1. Sotsialna psykholohiia osobystosti i spilkuvannia, p. 558. (in Ukrainian)

17. Osin E. (2004). Autentichnost. [Authenticity]. Ekzistentsialnaia traditsiia: Filosofiia, psikhologiia, psikhoterapiia. [Existential tradition: philosophy, psychology, psychotherapy]. Zhurnal Vostochno-Evropeiskoi assotsiatsii ekzistentsialnoi terapii. Rostov-na-Donu. Ed. 2, pp. 88-93. (in Russian)

18. Petrovskii V.A. (1996). Lichnost $\mathrm{v}$ psikhologii: paradigm subiektnosti [Personality in psychology: paradigm of subjectivity]. Rostov-na-Donu: «Feniks», p. 512. (in Russian)

19. Savchyn I.M. (2003). Systemna refleksiia yak mekhanizm samorehuliatsii zhyttiediialnosti osobystosti [Systemic reflection as a mechanism of self-regulation 


\section{Kravchenko Viktoria}

of life of personality]. Zbirnyk naukovyh prats: filosofia, sotsiolohiia, psykholohiia [Collection of scientific works: philosophy, sociology, psychology]. IvanoFrankivsk: Plai, Ed. 8. Ch. 1, p. 236. (in Ukrainian)

20. Sidorenko E.V. (2004). Metody matematicheskoi obrabotki v psikhologii [Methods of mathematical processing in psychology]. SPb.: OOO «Rech», p. 350. (in Russian)

21. Skripkina T.P. (2006). Deformatsiia doveritelnyh otnoshenii kak factor dezadaptatsii lichnosti [Deformation of trusting relationships as a factor of personal disadaptation]. Obshchenie-2006: na puti $\mathrm{k}$ entsyklopedicheskomu znaniiu: Materialy konferentsii (19-21 oktiabria 2006 g.) [Communication-2006: on the way to encyclopedic knowledge. Conference materials (19-21 of October, 2006]. Psihologicheskii institut RAO. - Moscow: Akademiia imidzheologii, pp. 555-561. (in Russian)

22. Skripkina T.P. (2000). Psikhologiia doveriia: [ucheb. posobiie dlia vyssh. ped. ucheb. zavedenii] [Psychology of trust: tutorial for high pedagogical institutions]. Moscow: Izdatelskii dom «Akademiia», p. 264. (in Russian)

23. Shapar V.B. (2004). Psykholohichnyi tlumachnyi slovnyk [Psychological explanatory dictionary]. Kharkiv: Prapor, p. 640. (in Ukrainian)

24. Sheremeta V.Yu. (2007). Psykholohichnyi analiz vplyvu samorefleksii na formuvannia doviry do sebe [Psychological analysis of influence of self-reflection on building of personal confidence]. Zbirnyk naukovyh prats: filosofiia, sotsiolohiia, psykholohiia [Collection of scientific works: philosophy, sociology, psychology]. Ivano-Frankivsk: VDV TSIT, Ed. 12. Ch. 1, pp. 242-248. (in Ukrainian)

25. Sheremeta V.Yu. (2007). Sotsialni funktsii doviry [Social functions of trust]. Problemy zahalnoi ta pedahohichnoi psykholohii. Zbirnyk naukovyh prats Instytutu psykholohii im. H.S. Kostiuka APN Ukrainy, vol. IX. Ch. 1. Kuiv, pp. 437-444. (in Ukrainian)

26. Tytarenko T.M., Zlobina O.H., Liepikhova L.A. ta in. (2012). Yak buduvaty vlasne maibutnie: zhyttievi zavdannia osobystosti: [nauk. monohr.] [How to build own future: personal life tasks]. eds. T.M. Tytarenko. Natsionalna akademiia pedahohichnyh nauk Ukrainy, Instytut sotsialnoi ta politychnoi psykholohii. Kirovohrad: Imeks-LTD, p. 512. (in Ukrainian) 